\title{
Lacrimal Gland Pleomorphic Adenoma
}

National Cancer Institute

\section{Source}

National Cancer Institute. Lacrimal Gland Pleomorphic Adenoma. NCI Thesaurus. Code C4542.

A benign, usually encapsulated neoplasm of the lacrimal gland composed of epithelial and mesenchymal cells. Pleomorphic adenomas are neoplasms that develop in the salivary glands or heterotopic salivary gland tissues. It has been suggested that myoepithelial cells play a major role in the histogenesis of these tumors. In the lacrimal gland, pleomorphic adenomas presumably develop from metaplastic myoepithelial cells. --2003 